\title{
250 labels used to stigmatise people with mental illness Diana Rose ${ }^{1}$, Graham Thornicroft ${ }^{* 2}$, Vanessa Pinfold ${ }^{3}$ and Aliya Kassam ${ }^{2}$
}

Address: ${ }^{1}$ Service User Research Enterprise, Health Service and Population Research Department, Institute of Psychiatry, King's College London, London, UK, 2Section of Community Mental Health Health Service and Population Research Department Institute of Psychiatry, King's College London, London, UK and ${ }^{3}$ Rethink severe mental illness, Royal London House, Finsbury Square, London, UK

Email: Diana Rose - d.rose@iop.kcl.ac.uk; Graham Thornicroft* - g.thornicroft@iop.kcl.ac.uk; Vanessa Pinfold - vanessa.pinfold@rethink.org; Aliya Kassam - aliya.kassam@iop.kcl.ac.uk

* Corresponding author

Published: 28 June 2007

BMC Health Services Research 2007, 7:97 doi:10.1186/1472-6963-7-97
Received: 16 january 2007

Accepted: 28 June 2007

This article is available from: http://www.biomedcentral.com/1472-6963/7/97

(c) 2007 Rose et al; licensee BioMed Central Ltd.

This is an Open Access article distributed under the terms of the Creative Commons Attribution License (http://creativecommons.org/licenses/by/2.0), which permits unrestricted use, distribution, and reproduction in any medium, provided the original work is properly cited.

\begin{abstract}
Background: The stigma against people with mental illness is a major barrier to help-seeking in young people for mental health problems. The objective of this study was to investigate the extent of stigma in relation to treatment avoidance in 14 year-old school students in England in relation to how they refer to people with mental illness.
\end{abstract}

Methods: This is a qualitative, cross-sectional study. The data were gathered as part of the baseline assessment for an intervention study intended to reduce stigma among 14 year old school students. The participating schools were two grammar (selective) schools and three comprehensive (nonselective) schools. At the start of the lesson, the students were asked 'What sorts of words or phrases might you use to describe someone who experiences mental health problems?' Words and terms used to refer to mental illness were enumerated. Using the grounded theory approach, words and terms were grouped in terms of their denotative and connotative meanings. Labels were then derived to capture the key themes attached by the students to the concepts of mental illness. The frequencies of occurrence for each word were also tabulated.

Results: 400 of the 472 participating students (85\%) provided 250 words and terms to describe a person with mental illness. Five themes were identified from the data. The first theme called 'popular derogatory terms' (II6 items) accounted for nearly half of the words examined. The second theme occurred less often and was described as 'negative emotional state' (6I items). The third theme demonstrated the confusion of young people between physical disabilities, learning difficulties and mental health problems (38 items). The use of psychiatric diagnoses ( 15 items) and terms related to violence ( 9 items) were unexpectedly uncommon.

Conclusion: Our findings suggest the hypothesis that help-seeking by mentally ill young people may be improved by interventions that address both their lack of factual information about mental illness, and those which reduce their strong negative emotional reactions towards people with mental illness. 


\section{Background}

Most young people who are mentally ill do not seek help [1-5]. Yet mental illnesses among children and adolescents are common, affecting about $10 \%$ of young people $[6,7]$. The rates for some mental disorders, including suicide, are increasing $[8,9]$. Up to half of those who fail to complete secondary school have mental illness [10]. Those who do, more often turn to friends and family for help than to health professionals [11,12]. Teenagers seek help less often than adults [13]. As few as $4 \%$ of young people with a mental illness seek help from a family doctor [14], and consultation rates are especially low among young men [15]. This paper argues that the stigma against mental illness is a powerful (and potentially reversible) contributory factor towards the reluctance of many young people to seek help for mental illness.

Research on help-seeking has paid particular attention to the confidentiality of healthcare, young people's knowledge about services, and how accessible they are [16]. But such factors do not fully explain the very low rates of consultation among young people who are mentally ill $[17,18]$. Recent work has focussed attention on whether young people know enough to allow them to correctly identify mental illness in themselves or in their peers (so called 'mental health literacy') [19], and upon their emotional/attitudinal responses (and associated stigma) to people with mental illness, as potential explanatory factors for help-seeking or help-avoidance [20].

Stigma is a term which has evaded clear, operational definition [21-24]. It can be considered as an amalgamation of three related problems: a lack of knowledge (ignorance), negative attitudes (prejudice), and excluding or avoiding behaviours (discrimination) [25-27]. In relation to knowledge about mental illness it is clear that there are striking knowledge gaps. [28-30]. For example, in Scotland most children do not know what to do if they have a mental health problem, or what to recommend to a friend with mental health difficulties. Only $1 \%$ mentioned school counselling, $1 \%$ nominated helplines, $4 \%$ recommended talking with friends, $10 \%$ said that they would turn to a doctor, but over a third (35\%) were unsure where to find help [31].

There is also fairly strong evidence that negative emotions and attitudes act as barriers to care. Compared with adults, young people have less favourable attitudes towards people with mental illness [32]. Conversely, young people with mental illness may be exposed to higher levels of stigma than adults [33]. Commonly young people feel that mental illness is embarrassing [34], should be handled privately, and people with these views tend to seek help less often [35-37]. Attributions for the cause of the condition are also important. Young people who believe that mental illnesses are the responsibility of the person affected are more likely to react to people who are mentally ill with anger, pitilessness or avoidance [38]. There are therefore grounds to consider that stigma may be one important factor in reducing help-seeking for mental illnesses, for example by avoiding the embarrassment of diagnosis $[37,39,40]$.

A recent study investigated whether accurate recognition and labelling of mental disorders by young people (aged 12 to 25 years) is associated with better help-seeking preferences [41]. After being shown a vignette of either a young person with depression or psychosis, each participant was asked what they thought was wrong with the person in the vignette, how long the person should wait to get help and what form of help they should seek. The results showed that the young people who correctly labelled the disorder were also those who most identified appropriate help-seeking and treatment options. Although the Wright et al. study explored help-seeking directly, the stigmatising attitudes and beliefs held by young people towards mental illness and people with mental illness which may deter them from seeking help were not explored. The purpose of our study was to determine what young people actually think about mental illness/people with mental illness and explore the type of language they use to label it.

\section{Methods}

Much stigma-related research has used vignettes or social distance scales which may constrain what respondents can express about stigma. Our method was intended to allow young people to express what they thought about mental illness in a way that was not pre structured by attitude scales or vignettes. To explore the role of stigma in relation to treatment avoidance further, we describe here the terms used by 14 year-old school students in England to refer to people with mental illness. These data were gathered as a part of the baseline assessment in an intervention study intended to reduce stigma among school students. Full details of the method are given elsewhere [42]. Briefly, members of Mid-Kent Mental Health Awareness group, including service users, delivered two educational sessions in 5 local secondary schools. Two educational lessons, each one hour long, were given within the Personal Social Health and Education curriculum students aged 14 . The participating centres were two grammar (single-sex selective state) school, and three comprehensive (co-educational, non-selective state) schools, typical of those in the local area. At the start of the lesson the young people filled out baseline questionnaires where they were asked 'What sorts of words or phrases might you use to describe someone who experiences mental health problems?' The project was approved by the local research ethics committee. 
The data analysis was deliberately straightforward. First we enumerated the words and terms used to refer to mental illness. Although some of the young people elaborated a little upon the words they chose, most of the data consisted of single words. The first part of the analysis was to tabulate them in order of frequency where the words or terms were offered by at least 3 different students. This was done to map the meanings that students gave to mental illness in terms of their relative importance. Secondly, using the approach of grounded theory [43], the words were grouped in terms of both their denotative and connotative meanings, and labels were derived which captured the key themes attached by the young people to these concepts of mental illness. Denotative meanings are what a term refers to, what it 'names', and connotative meanings are the associations, values, and judgements that surround this. A preliminary examination of our material suggested that connotative meanings would be very significant. We went on to calculate the frequencies of occurrence for each category, and finally over-arching concepts were derived.

\section{Results}

Of the 634 14-year old students identified in the four schools, 472 (74\%) students received both of the two mental health awareness workshops and completed baseline and follow-up assessments. Of these 400 (85\%) pupils provided 250 words and terms, and 20 longer phrases, to describe a person with a mental health problem in their baseline assessment. The sample was predominantly female $(73 \%)$. Fifty two per-cent of the sample attended co-education state schools whilst $48 \%$ attended single sex grammar schools. Two hundred and eight students (52\%) reported that they personally knew someone with mental illness.

Table 1 show the 44 most frequently occurring words and terms, namely those that were stated by 3 or more students. Three quarters $(n=33)$ of these terms are strongly negative in referring to people with mental health problems. Seven terms $(16 \%)$ of those shown were broadly neutral, including the use of medical diagnostic terms, and only $4(9 \%)$ could be described as at all empathic or eliciting compassion, 'sad' or 'isolated'.

We identified five themes which emerged from these data (Table 2). The labels used for these themes reflect the overwhelmingly negative connotations used by young people to describe people with mental health problems. The first theme accounts for nearly half the words (116 items) we examined. We have termed this 'popular derogatory terms', and they are in effect 'slang'. In terms of the distinction between denotative and connotative meaning, these terms appear to have no referent but are a set of negative associations and judgements in and of themselves.
Table I: Most frequently occurring words and terms

\begin{tabular}{lcll}
\hline Term & Frequency & Term & Frequency \\
\hline Disturbed & II & Scary & 5 \\
Nuts & II & Div & 4 \\
Confused & 10 & Dumb & 4 \\
Psycho & 10 & III & 4 \\
Spastic & 10 & Loneliness & 4 \\
Crazy & 9 & Loony bin & 4 \\
Depression & 7 & Psychiatric & 4 \\
Disabled & 7 & Screw loose & 4 \\
Mad & 7 & Stress & 4 \\
Unpredictable & 7 & Violence & 4 \\
Insane & 6 & Brain dead & 3 \\
Loony & 6 & Demanding & 3 \\
Mental & 6 & Demented & 3 \\
Schizophrenia & 6 & Dinlo & 3 \\
Thicko & 6 & Distressed & 3 \\
Weird & 6 & Embarrassed & 3 \\
Depressed & 5 & Flid & 3 \\
Different & 5 & Frustrated & 3 \\
Freak & 5 & Isolated & 3 \\
Odd & 5 & Sad & 3 \\
Problem & 5 & Strait jacket & 3 \\
Retard & 5 & Wheel chairs & 3 \\
& & & \\
\hline
\end{tabular}

The second theme occurred about half as often as the first, and is described as 'negative emotional state' (61 items). Not one positive emotional state was mentioned. The most frequently mentioned words were 'disturbed' and 'confused'. These are powerful terms and appear to reflect anxiety on the part of respondents when thinking about mental health problems and the people affected by them.

The third theme demonstrates confusion by the young people between physical disabilities, learning difficulties and mental health problems (38 items). It is notable that the young people hardly used formal psychiatric diagnoses (the fourth theme) at all, preferring the use of emotionally-charged negative terms which represent people with mental illness as someone having a physical disability (15 items).

Against our expectations, the fifth theme of violence was relatively rare ( 9 items). This is surprising given that psychiatric patients are so often portrayed by the UK media as perpetrators of violence. We have no explanation for why the theme of violence was used in such a limited way, except to say that many of the derogatory terms have a covert connotation, referring to something to be feared. Only two terms made up the final theme of sadness and isolation, but they do have a slightly more positive connotation than the rest of the material. Isolation and loneliness suggest pity rather than fear.

More striking was the sheer range and emotional power of the words used $(\mathrm{n}=250)$ showing both a remarkable vir- 
Table 2: Super-ordinate categories emerging from the terms used

\begin{tabular}{lllllll}
\hline Theme & $\begin{array}{l}\text { I Popular derogatory } \\
\text { terms }\end{array}$ & $\begin{array}{l}\text { 2 Negative } \\
\text { Emotional State }\end{array}$ & $\begin{array}{l}\text { 3 Physical Illness or } \\
\text { Learning Disability }\end{array}$ & $\begin{array}{l}\text { 4 Psychiatric } \\
\text { categories }\end{array}$ & $\mathbf{5}$ Violence & $\mathbf{6}$ Loneliness \\
\hline Number of instances & II4 & 61 & 38 & 15 & 9 & 10 \\
Examples & Nuts & Disturbed & Disabled & Schizophrenia & Scary & Isolated \\
& Psycho & Confused & Spastic & Depression & Violence & Loneliness \\
& Crazy & Depression & Dumb & Psychiatric & & \\
& Loony & III & Demented & & \\
& Weird & Stress & Wheelchairs & & \\
& Freak & Distressed & & & \\
& Screw Loose & Embarrassed & & &
\end{tabular}

tuosity (encroaching upon the vulgar) and a lack of precision in how students expressed themselves when speaking about people with mental illness (see Table 3 ).

\section{Discussion}

How do young people learn such wide-ranging, emotionally-charged and negative terms about mental illness? The primary sources appear to be from the media, and from family and peers [44-46]. Derogatory references about people with mental illness appear commonly in the print, broadcast and cinematographic media $[47,48]$. For television and newspaper items about mental illness, for example, between one third and two thirds refer primarily to violence [25]. The highest rate of such negative coverage occurs in children's animations, where up to two-thirds of all references are to violence $[49,50]$. Interestingly, almost a half $(46 \%)$ of all the episodes contained some reference to mental illness, especially in cartoons, where the vocabulary analysed in one New Zealand study was 'predominantly negative fundamentally disrespectful. The characters were typically losing control, constantly engaged in illogical and irrational actions', and were 'stereotypically and blatantly negative, and served as objects of amusement, derision or fear.' [50] Children's programmes in the USA have produced almost identical results, where the images were 'typically used to disparage and ridicule' $[44,51]$. More specifically, a Canadian study examined Disney animated films for children and found that $85 \%$ contained verbal references to mental illness and they were mainly used to 'set apart and denigrate' the characters [52].

Our results, alongside previous research, suggest the following conclusions. First, the level of factual knowledge among 14 year old school children about mental illness is remarkably low, and this may partially explain why their rates of recognition of mental illness are poor. The magnitude of this information gap has previously been underestimated [53]. Second, the strongly negative emotions described in this paper offer a route for future investigation on whether this helps to explain why young people, even more than adults [54-56], are so reluctant to seek help when experiencing mental illness, and often tend to feel that they should cope alone [57].

Our methodological approach has three important limitations. First, our method of data collection may be described as over-simplistic. However, our method has given a clear account of the full range of language used by young people when referring to mental illness which would be difficult otherwise to ascertain and so this study can be used as a benchmark for future research. Second, as the study was predominantly female, the sample size did not allow us to explore important possible gender differences, for example whether the words and terms used suggested a greater degree of mental health literacy for female students [58]. Third, the nature of the results, very largely showing the use of negative terminology, did not allow us to establish whether those students with personal contact with people with mental illness used systematically more favourable terms.

\section{Conclusion}

An appreciation of both factual ignorance and the degree of emotionally-charged prejudice by school students against people with mental illness is necessary when planning interventions intended to improve help-seeking $[25,59,60]$. The strongest evidence-based intervention known to reduce stigmatising attitudes (but not yet shown to change discriminatory behaviour) is direct social contact with a person who has mental illness $[21,26,42,61,62]$. Our findings, if replicated, suggest that help-seeking by mentally ill young people may be improved by interventions that address both their lack of factual information about mental illness, and those which reduce their strong negative emotional reactions towards people with mental illness [63].

\section{Competing interests}

The author(s) declare that they have no competing interests. 
Table 3: Terms used by 14 year old school students to refer to mental illness

\begin{tabular}{|c|c|c|c|}
\hline Abnormal & Frustration & Not fair & Sometimes lacking brain power \\
\hline Abusive & Fucked & Not happy & Spakka \\
\hline Alone & Funny & Not obvious & Spanner \\
\hline Alzheimers & Gay & Not quite there & Spastic \\
\hline Angry & Get lost & Not the sharpest knife in the drawer & Spaz \\
\hline Anti-social & Gone in the head & Numscull & Split personality \\
\hline Asylums & Goon & Nutcase & Spoone \\
\hline Attention seekers & Green room & Nutter & Stiggy nutter \\
\hline Autism & Halfwit & Nuts & Stigma \\
\hline Bewildered & Hallucinating & Nutty as a fruitcake & Strait jackets \\
\hline Bimbo & Hallucinations & OCD & Strange \\
\hline Bonkers & Hand fed & Odd & Stress \\
\hline Brain damage & Handicapped & Oddball & Stressed \\
\hline Brain dead & Happy club & Off their rocker & Therapist \\
\hline Breakdown & Hard & Out of it & Therapy \\
\hline Childish & Hard work & Outcast & Thick \\
\hline Cola sweat & Head banging & Padded cells & Thicko \\
\hline Confused & Head case & Paedophile & Thicky \\
\hline Crackers & Helpless & Panicked & Tiring \\
\hline Crazy & Hurting yourself & Paranoid & Too much pressure \\
\hline Cushioned walks & Idiot & Patch Adams & Touchy to talk to \\
\hline Dangerous & III & People who are obsessed & Troubled \\
\hline Deformed & Indecisive & Perfectly normal & Twisted \\
\hline Demanding & Infixed in bad habits & Perverted & Twister \\
\hline Demented & Insane & Physical problems & Ugly \\
\hline Depressed & Insecure & Physically ill & Unable to make decisions \\
\hline Depression & Intellectually challenged & Pills & Unappreciated \\
\hline Deranged & Intimidating & Pinflump & Unapproachable \\
\hline Difficulty learning & Irrational & Pive & Uncomfortable \\
\hline Dildo & Isolated & Plank & Under pressure \\
\hline Dinlo & Joe from Eastenders & Ponce & Understandable \\
\hline Disabled & Jumpy & Pressure & Unfair \\
\hline Disarmed & Learning difficulties & Pressurising families & Unfortunate \\
\hline Disorientated & Lonely & Problems & Unhappy \\
\hline Distorted & Loony & Psychiatric & Unpredictable \\
\hline Distressed & Loony bin & Psychiatric health & Unstable \\
\hline Distressing & Loser & Psychiatrist & Upsetting \\
\hline Disturbed & Lost & Psycho & Veg \\
\hline Disturbing & Lunatic & Psychopath & Vegetable \\
\hline Disturbing images & Mad & Reject & Victim \\
\hline Div & Made fun of & Retard & Victimised \\
\hline Dizzy & Madness & Sad & Violence \\
\hline Doctors & Manic depression & Sandwich/pepperoni short of a picnic & Violent \\
\hline Dofuss & Mass murderers & Scared & Voices \\
\hline Dopy & M.E. & $\begin{array}{l}\text { Scared to talk to if they were a } \\
\text { murderer or rapist }\end{array}$ & Voices in your head \\
\hline Downy & Mental & Scary & Vulnerable \\
\hline Dribbling & Mental hospital & Schizo & Wacky \\
\hline Drugged-up & Mental illness & Schizophrenia & Wally \\
\hline Dulally & Mental institution & Schizophrenic & War \\
\hline Dumb & Mentally challenged & School can cause it & Wheelchair jockey \\
\hline Embarrassed & Mentally handicapped & School pressure & Weird \\
\hline Embarrassing & Mentally ill & Screw loose & Weirdo \\
\hline Empty & Misunderstood & Screwed & Wheel chairs \\
\hline Escaped from an asylum & Mong & Sees things in a different way & White coats \\
\hline Excluded & More common than you think & Segregation & Wild \\
\hline Feel sorry & Muppets & Self-harm & Wild funny noises \\
\hline Few sandwiches short of a picnic basket & Needing help & Shock syndrome & Window licker \\
\hline Flid & Nervous & Shouts & Withdrawn \\
\hline Flip in the head & Nightmares & Sick in the head & World of their own \\
\hline Freak & Non-caring & Simple & Worried \\
\hline Fruit cake & None caring & Simpleton & You belong in a home \\
\hline Frustrated & No-one upstairs & Some people born mentally ill & \\
\hline Frustrating & Not all there & Sometimes includes drugs & \\
\hline
\end{tabular}




\section{Authors' contributions}

GT and VP secured the grant for this work, and conducted the study. DR, AK, GT and VP together analysed and interpreted the data for the part of the study reported in this paper. All authors read and approved the final manuscript.

\section{Acknowledgements}

This work was funded by an education grant by Lundbeck UK. The authors are independent of the funder. We would like to acknowledge the very helpful comments of Dr. Ann Law on earlier drafts of this paper.

\section{References}

I. Sawyer MG, Arney FM, Baghurst PA, Clark JJ, Graetz BW, Kosky RJ, Nurcombe B, Patton GC, Prior MR, Raphael B, Rey JM, Whaites LC, Zubrick SR: The mental health of young people in Australia: key findings from the child and adolescent component of the national survey of mental health and well-being. Aust N Z J Psychiatry 200I, 35:806-8I4.

2. Zachrisson HD, Rodje K, Mykletun A: Utilization of health services in relation to mental health problems in adolescents: a population based survey. BMC Public Health 2006, 6:34.

3. Kessler RC, Demler O, Frank RG, Olfson M, Pincus HA, Walters EE, Wang $P$, Wells KB, Zaslavsky AM: Prevalence and treatment of mental disorders, 1990 to 2003. N Engl J Med 2005, 352:2515-2523.

4. Weiss MF: Children's attitudes toward the mentally ill: an eight-year longitudinal follow-up. Psychol Rep |994, 74:51-56.

5. Bailey S: Young people, mental illness and stigmatisation. Psychiatric Bulletin 1999, 23:107-II0.

6. Ford T, Goodman R, Meltzer H: The British Child and Adolescent Mental Health Survey I999: the prevalence of DSM-IV disorders. J Am Acad Child Adolesc Psychiatry 2003, 42: I 203-I2I I.

7. Bilenberg N, Petersen DJ, Hoerder K, Gillberg C: The prevalence of child-psychiatric disorders among 8-9-year-old children in Danish mainstream schools. Acta Psychiatr Scand 2005 , I I I:59-67.

8. McClure GM: Suicide in children and adolescents in England and Wales I 970-1998. Br J Psychiatry 200I, I 78:469-474.

9. Costello EJ, Foley DL, Angold A: I 0-year research update review: the epidemiology of child and adolescent psychiatric disorders: II. Developmental epidemiology. I Am Acad Child Adolesc Psychiatry 2006, 45:8-25.

10. Stoep AV, Weiss NS, Kuo ES, Cheney D, Cohen P: What proportion of failure to complete secondary school in the US population is attributable to adolescent psychiatric disorder? Behav Health Serv Res 2003, 30: I 19-124.

II. Evans E, Hawton K, Rodham K: In what ways are adolescents who engage in self-harm or experience thoughts of self-harm different in terms of help-seeking, communication and coping strategies? J Adolesc 2005, 28:573-587.

12. Jorm AF, Medway J, Christensen H, Korten AE, Jacomb PA, Rodgers $B$ : Attitudes towards people with depression: effects on the public's help-seeking and outcome when experiencing common psychiatric symptoms. Aust N Z J Psychiatry 2000, 34:612-618.

13. Oliver MI, Pearson N, Coe N, Gunnell D: Help-seeking behaviour in men and women with common mental health problems: cross-sectional study. Br I Psychiatry 2005, 186:297-30I.

14. Potts Y, Gillies ML, Wood SF: Lack of mental well-being in 15 year-olds: an undisclosed iceberg? Fam Pract 200I, I 8:95-100.

15. Biddle L, Gunnell D, Sharp D, Donovan JL: Factors influencing help seeking in mentally distressed young adults: a cross-sectional survey. Br / Gen Pract 2004, 54:248-253.

16. Booth ML, Bernard D, Quine S, Kang MS, Usherwood T, Alperstein G, Bennett DL: Access to health care among Australian adolescents young people's perspectives and their sociodemographic distribution. J Adolesc Health 2004, 34:97- 103.

17. Tyssen R, Rovik JO, Vaglum P, Gronvold NT, Ekeberg O: Help-seeking for mental health problems among young physicians: is it the most ill that seeks help? - A longitudinal and nationwide study. Soc Psychiatry Psychiatr Epidemiol 2004, 39:989-993.
18. Zwaanswijk M, van der EJ, Verhaak PF, Bensing JM, Verhulst FC: Factors associated with adolescent mental health service need and utilization. J Am Acad Child Adolesc Psychiatry 2003, 42:692-700.

19. Burns JR, Rapee RM: Adolescent mental health literacy: Young people's knowledge of depression and help seeking. J Adolesc 2006, 29:225-239.

20. Angermeyer MC, Matschinger H, Riedel-Heller SG: Whom to ask for help in case of a mental disorder? Preferences of the lay public. Soc Psychiatry Psychiatr Epidemiol 1999, 34:202-210.

21. Keusch GT, Wilentz J, Kleinman A: Stigma and global health: developing a research agenda. Lancet 2006, 367:525-527.

22. Link BG, Phelan JC: Stigma and its public health implications. Lancet 2006, 367:528-529.

23. Jamison KR: The many stigmas of mental illness. Lancet 2006 , 367:533-534.

24. Jacoby A, Snape D, Baker GA: Epilepsy and social identity: the stigma of a chronic neurological disorder. Lancet Neurol 2005 4:|7|-|78.

25. Thornicroft G: Shunned: Discrimination against People with Mental Illness Oxford, Oxford University Press; 2006.

26. Corrigan P: On the Stigma of Mental Illness Washington,D.C., American Psychological Association; 2005.

27. Sartorius N, Schulze H: Reducing the Stigma of Mental Illness. A Report from a Global Programme of the World Psychiatric Association Cambridge, Cambridge University Press; 2005

28. Gasquet I, Chavance M, Ledoux S, Choquet M: Psychosocial factors associated with help-seeking behavior among depressive adolescents. Eur Child Adolesc Psychiatry 1997, 6: I5 I- I59.

29. Secker J, Armstrong C, Hill M: Young people's understanding of mental illness. Health Educ Res 1999, I 4:729-739.

30. Hinshaw SP, Cicchetti D: Stigma and mental disorder: conceptions of illness, public attitudes, personal disclosure, and social policy. Dev Psychopathol 2000, I 2:555-598.

31. Scotland SM: The Second National Public Attitudes Survey, 'Well? What do you think?' Edinburgh, Scottish Executive; 2004.

32. Stuart $\mathrm{H}$, Arboleda-Florez J: Community attitudes toward people with schizophrenia. Canadian Journal of Psychiatry 2001, 46:245-252.

33. Thara R, Srinivasan TN: How stigmatising is schizophrenia in India? Int / Soc Psychiatry 2000, 46:|35-|4|.

34. Barney LJ, Griffiths KM, Jorm AF, Christensen H: Stigma about depression and its impact on help-seeking intentions. Aust $N$ Z J Psychiatry 2006, 40:5 I-54.

35. Corrigan PW, Lurie BD, Goldman HH, Slopen N, Medasani K, Phelan $\mathrm{S}$ : How adolescents perceive the stigma of mental illness and alcohol abuse. Psychiatr Serv 2005, 56:544-550.

36. Gould MS, Velting D, Kleinman M, Lucas C, Thomas JG, Chung M: Teenagers' attitudes about coping strategies and help-seeking behavior for suicidality. J Am Acad Child Adolesc Psychiatry 2004, 43: I I24-II33.

37. Chew-Graham CA, Rogers A, Yassin N: 'I wouldn't want it on my CV or their records': medical students' experiences of helpseeking for mental health problems. Med Educ 2003 , 37:873-880

38. Corrigan PW, Lurie BD, Goldman HH, Slopen N, Medasani K, Phelan S: How adolescents perceive the stigma of mental illness and alcohol abuse. Psychiatr Serv 2005, 56:544-550.

39. Saldivia S, Vicente B, Kohn R, Rioseco P, Torres S: Use of mental health services in Chile. Psychiatr Serv 2004, 55:71-76.

40. Hugo CJ, Boshoff DE, Traut A, Zungu-Dirwayi N, Stein DJ: Community attitudes toward and knowledge of mental illness in South Africa. Soc Psychiatry Psychiatr Epidemiol 2003, 38:7I 5-7I9.

41. Wright A, Jorm A, Harris MG, McGorry PD: What's in a name? Is accurate recognition and labelling of mental disorders by young people associated with better help-seeking and treatment preferences? Soc Psychiatry Psychiatr Epidemiol 2007, 42:244-250.

42. Pinfold V, Toulmin H, Thornicroft G, Huxley P, Farmer P, Graham T: Reducing psychiatric stigma and discrimination: evaluation of educational interventions in UK secondary schools. $\mathrm{Br} J \mathrm{Psy}-$ chiatry 2003, I 82:342-346.

43. Strauss A, Corbin J: Basics of Qualitative Research: Techniques and Procedures for Developing Grounded Theory Newbury Park, California, Sage; 1990.

44. Wahl OF: Depictions of mental illness in children's media Journal of Mental Health 2003, I 2:249-258. 
45. Adler AK, Wahl OF: Children's beliefs about people labeled mentally ill. Am J Orthopsychiatry 1998, 68:32I-326.

46. Dietrich S, Heider D, Matschinger H, Angermeyer MC: Influence of newspaper reporting on adolescents' attitudes toward people with mental illness. Soc Psychiatry Psychiatr Epidemiol 2006, 4I:318-322.

47. Philo G: Media and Mental Distress London, Longman; 1996

48. Wahl OF: Media Madness: Public Images of Mental Illness New Brunswick, New Jersey, Rutgers University Press; 1995.

49. Cutcliffe JR, Hannigan B: Mass media, 'monsters' and mental health clients: the need for increased lobbying. J Psychiatr Ment Health Nurs 200I, 8:315-32I.

50. Wilson C, Nairn R, Coverdale J, Panapa A: How mental illness is portrayed in children's television. A prospective study. $\mathrm{Br}$ Psychiatry 2000, 176:440-443.

51. Wahl O: Mental illness depiction in children's films. Journal of Community Psychology 2003:553-560.

52. Lawson A, Fouts G: Mental illness in Disney animated films. Can J Psychiatry 2004, 49:310-3I4.

53. Weiss MG, Ramakrishna J: Stigma interventions and research for international health. Lancet 2006, 367:536-538.

54. Wrigley S, Jackson H, Judd F, Komiti A: Role of stigma and attitudes toward help-seeking from a general practitioner for mental health problems in a rural town. Aust $N \mathrm{Z}$ J Psychiatry 2005, 39:5I4-52I.

55. Sirey JA, Bruce ML, Alexopoulos GS, Perlick DA, Raue P, Friedman SJ, Meyers BS: Perceived stigma as a predictor of treatment discontinuation in young and older outpatients with depression. Am J Psychiatry 200I, I 58:479-48I.

56. Barney LJ, Griffiths KM, Jorm AF, Christensen H: Stigma about depression and its impact on help-seeking intentions. Aust $\mathrm{N}$ ZJ Psychiatry 2006, 40:5 I-54.

57. Jorm AF, Kelly CM, Wright A, Parslow RA, Harris MG, McGorry PD: Belief in dealing with depression alone: results from community surveys of adolescents and adults. J Affect Disord 2006, 96:59-65.

58. Cotton SM, Wright A, Harris MG, Jorm AF, McGorry PD: Influence of gender on mental health literacy in young Australians. Aust N Z J Psychiatry 2006, 40:790-796.

59. Michels KM, Hofman KJ, Keusch GT, Hrynkow SH: Stigma and global health: looking forward. Lancet 2006, 367:538-539.

60. Wright A, Harris MG, Wiggers JH, Jorm AF, Cotton SM, Harrigan SM, Hurworth RE, McGorry PD: Recognition of depression and psychosis by young Australians and their beliefs about treatment. Med J Aust 2005, I 83: I8-23.

61. Jamison KR: The many stigmas of mental illness. Lancet 2006, 367:533-534.

62. Corrigan PW, River LP, Lundin RK, Penn DL, Uphoff-Wasowski K Campion J, Mathisen J, Gagnon C, Bergman M, Goldstein H, Kubiak MA: Three strategies for changing attributions about severe mental illness. Schizophrenia Bulletin 200I, 27:187-195.

63. Wright A, McGorry PD, Harris MG, Jorm AF, Pennell K: Development and evaluation of a youth mental health community awareness campaign - The Compass Strategy. BMC Public Health 2006, 6:215.

\section{Pre-publication history}

The pre-publication history for this paper can be accessed here:

http://www.biomedcentral.com/1472-6963/7/97/prepub
Publish with Biomed Central and every scientist can read your work free of charge

"BioMed Central will be the most significant development for disseminating the results of biomedical research in our lifetime. "

Sir Paul Nurse, Cancer Research UK

Your research papers will be:

- available free of charge to the entire biomedical community

- peer reviewed and published immediately upon acceptance

- cited in PubMed and archived on PubMed Central

- yours - you keep the copyright
BioMedcentral 